\title{
The Effect of Constructivism and Whole Language Approach to Poetry Writting Skills
}

\author{
Brigida Sri Purwaningsih \\ \{brigida.sri.purwaningsih@gmail.com\} \\ Universitas Muria Kudus, Kudus, Central Java 59327, Indonesia
}

\begin{abstract}
This research is motivated by the difficulty of elementary students in writing poetry because of (1) the lack of vocabulary from students , (2) the language used is still simple, and (3) unable to express ideas that are appropriate in learning. The teacher also has not tried to implement other approaches that can motivate students to be able to write poetry according to the aspects in poetry. This study aims to find out how much improvement in poetry writing skills of fourth grade students in Group Rajawali Rembang Subdistrict, Rembang Regency using the Constructivism and Whole Language approaches, and to find out the difference between Constructivism and Whole Language approaches in influencing poetry writing skills. This research is a quantitative research that uses a type of quasi-experimental research with experimental groups and control groups selected without random assignment. The population in this study were elementary school students spread in 47 elementary schools with 8 groups located in Rembang District, Rembang Regency. Based on the random sampling technique, 4 elementary schools were assigned as the experimental group and the other 2 elementary schools as the control group. Data analysis techniques is used by grouping the data based on variables, tabulating data and submitting the data for each variable under study. Testing is done using the SPSS 23 program for Windows.
\end{abstract}

Keywords : Constructivism Approach, Whole Language, Poetry Writing Skills.

\section{PRELIMINARY}

The preparation of language and literary material is the integration of the four skills. The four language skills, namely listening, speaking, reading and writing skills that are developed together and integrated are not fragmented. In its implementation related to the chosen theme, according to the themes suggested in the curriculum (St. Y.Slamet, 2014: 71).

Of the four language skills, reading and writing are complementary activities. Writing habits are not possible without reading habits. Although reading habits are not necessarily written habits, reading habits will broaden the horizons of knowledge and insight. The language aspect of writing is focused so that students are able to express various thoughts, ideas, opinions, and feelings in composing essays, writing personal letters, summarizing reading books, making posters, and writing notes in a diary.

Whereas in the ability to write literature, the competency standards of writing aspects are integrated with other aspects of skills, namely students appreciating the variety of children's literature through listening and responding to short stories, writing simple prose, portraying children's drama without text, and writing free poetry (Depdikbud, 2006: 16)

The activity of writing free poetry of elementary school (SD) students is still relatively low. Because students tend not able to put ideas and thoughts in written form. This weakness is reinforced by the factor of teachers who are accustomed to emphasize theory rather than 
practice. Even though getting students used to writing ideas in written form is the right first step as a process of inculcating a creative writing culture. 
The factors of lack of success in writing poetry of elementary school students include students not being able to develop ideas or ideas, lacking wealth in vocabulary so that the language they compose is still simple, and lack of understanding in the use of capital letters.

Skill comes from the word skilled commonly used to describe a person's varying level of ability. Skill (skill) is the ability to operate work easily and carefully (Sri Widiastuti, 2010: 49). While the term skilled is also interpreted as an act or task and as an indicator of a level of proficiency (Amirullah Day 2003: 17)

Writing can be considered as a process or an outcome. Writing is an activity carried out by someone to produce an article (Puji Santoso, et al: 2008)

Poetry is a literary work in the form of strands of stanza after stanza which relatively considers the rhythm and rhyme so that it is truly beautiful and effective in a relatively short time compared to other forms of literary works (St.Y.Slamet: 2014)

Poetry writing is an activity carried out by a person to produce literary works in the form of string after verse by paying attention to the rhythm and rhyme so that it can be truly beautiful.

Approach to learning can be interpreted as a starting point or our perspective on the learning process that refers to the view of the occurrence of a process that is still very general in nature. In it embodies, inspires, strengthens, and underlies learning methods with a certain theoretical scope. Viewed from the approach to learning there are two types of approaches, namely (1) a learning approach that is oriented or student-centered (student centered approach) and (2) a teacher-oriented approach to learning (teacher centered approach) (Akhmad Sudrajat, 2008).

Constructivism in learning theory emphasizes the knowledge that is built by students themselves as a result of the experience that has been done. So that through learning activities that build their own concepts students will get meaningful learning (Murtono, 2017: 4)

An integrated approach to language learning is based on a holistic language view (whole language) which treats language as something round and whole. In essence, whole language is a philosophy of views or beliefs about learning and how children learn optimally Sabarti Akhadiah (in Hariyanto: 2009).

Moving on from the above background and discussion of the constructivism and whole language approaches this study will present a literature review of the causes of students' lack of success in poetry writing skills. The results of this study are expected to be material information for elementary school students in practicing poetry writing skills.

\section{RESEARCH METHODS}

This research uses descriptive research method. This method is used to analyze several possibilities to solve actual problems by collecting data, classifying, analyzing, and interpreting it. In this method implemented by describing the facts and then analyzed to provide understanding and explanation.

Data collection was carried out by studying literature and questionnaires. Literature review is a data collection technique by collecting and analyzing documents. Questionnaire is a data collection technique by asking written questions to be answered in writing. Some of the research stages used are: (1) Preparation stage, which is collecting and studying books literature related to the problem to be studied, conduct searches using the internet media and gather theories that support. prepare a questionnaire and permission to conduct initial observations by filling out student questionnaires. (2) Implementation stage, i.e. data collected 
at the preparation stage are analyzed for test the accuracy of the data. (3) Data management stage, which is processing the main data.

\section{RESEARCH RESULT}

The results of previous studies on poetry writing skills conducted by Sinta Arfiani (2016) using the audiovisual-assisted whole language approach were able to show an increase in student writing skills, teacher skills, and student learning activities.

Researchers who discussed poetry writing skills using a constructivism approach have been implemented by Affan Subandi (2013). Constructivist learning can improve students' ability to write poetry.

Indications of student learning outcomes can be observed from changes in student learning behavior through the stages of the learning process from the beginning to being able to write poetry obtained a percentage of success 86.67. The application of constructivist methods in learning resulted in an increase in the ability to write poetry in class X students at SMA Negeri 2 Genteng. Although the level of achievement of students' poetry writing abilities is not yet perfect.

Based on the results of a preliminary study conducted in six elementary schools in Rembang District, Rembang Regency writing poetry is a fun lesson but difficult to do. The results of the questionnaire distributed to 30 students from 6 schools obtained the following results:

Table 1. Results of the Initial Information Questionnaire Writing Poetry of Class IV Rajawali Clusters

\begin{tabular}{|c|c|c|c|c|}
\hline No & Questions & Yes & Some-times & No \\
\hline 1 & 1 Do you like poetry writing activities & $\begin{array}{c}8 \\
27,67 \%\end{array}$ & $\begin{array}{c}17 \\
56,67 \%\end{array}$ & $\begin{array}{c}5 \\
16,67 \%\end{array}$ \\
\hline 2 & $\begin{array}{l}\text { Do poetry writing activities often take place at } \\
\text { school? }\end{array}$ & $\begin{array}{c}2 \\
6,67 \%\end{array}$ & $\begin{array}{c}25 \\
83,33 \%\end{array}$ & $\begin{array}{c}3 \\
10,00 \%\end{array}$ \\
\hline 3 & $\begin{array}{l}\text { Do you find it difficult to get the task of writing } \\
\text { poetry at school? }\end{array}$ & $\begin{array}{c}17 \\
56,67 \%\end{array}$ & $\begin{array}{c}9 \\
30,00 \%\end{array}$ & $\begin{array}{c}4 \\
13,33 \%\end{array}$ \\
\hline 4 & $\begin{array}{l}\text { Have you ever gained knowledge about how to } \\
\text { write poetry? }\end{array}$ & $\begin{array}{c}3 \\
10,00 \% \\
\end{array}$ & $\begin{array}{c}5 \\
16,67 \% \\
\end{array}$ & $\begin{array}{c}22 \\
73,33 \% \\
\end{array}$ \\
\hline 5 & $\begin{array}{l}\text { Have you ever had the task of writing poetry at } \\
\text { home? }\end{array}$ & $\begin{array}{c}15 \\
50,00 \%\end{array}$ & $\begin{array}{c}10 \\
33,33 \%\end{array}$ & $\begin{array}{c}5 \\
16,67 \%\end{array}$ \\
\hline 6 & $\begin{array}{l}\text { Would you like to get a practical assignment to } \\
\text { write poetry at school? }\end{array}$ & $\begin{array}{c}18 \\
60,00 \%\end{array}$ & $\begin{array}{c}5 \\
16,67 \%\end{array}$ & $\begin{array}{c}7 \\
23,33 \%\end{array}$ \\
\hline 7 & $\begin{array}{l}\text { Do you have difficulty in composing words in } \\
\text { writing poetry?? }\end{array}$ & $\begin{array}{c}20 \\
66,67 \% \\
\end{array}$ & $\begin{array}{c}7 \\
23,33 \% \\
\end{array}$ & $\begin{array}{c}3 \\
10,00 \% \\
\end{array}$ \\
\hline 8 & $\begin{array}{l}\text { Do you find it difficult to use ideas and imagination } \\
\text { in writing poetry? }\end{array}$ & $\begin{array}{c}18 \\
60,00 \%\end{array}$ & $\begin{array}{c}10 \\
33,33 \%\end{array}$ & $\begin{array}{c}2 \\
6,67 \%\end{array}$ \\
\hline & Number of Respondents (percentage) & & $30(100 \%)$ & \\
\hline
\end{tabular}


In total 17 students or $56.67 \%$ stated that sometimes they liked poetry writing activities, students who liked poetry writing activities were only 8 students or $26.67 \%$, while 5 students or $16.67 \%$ said they did not like poetry writing activities. From the results of these answers it can be concluded that student interest in writing poetry is still low, so efforts are needed to increase student interest.

In total 25 students or $83.33 \%$ stated that poetry writing activities were sometimes carried out at school, while 3 students or $10.00 \%$ stated that poetry writing activities were never carried out at school, whereas students who stated poetry writing activities often conducted in schools only 2 students or $6.67 \%$. The information above shows that the learning to write poetry has not been carried out optimally in class.

Poetry writing learning that has not been carried out optimally results in less success in learning to write poetry, because to produce good poetry writing, it requires ongoing practice. There are only 4 students or around $13.33 \%$ of the students in the class who say that writing poetry is an easy activity. 17 students or $56.67 \%$ stated that writing poetry was a difficult activity, and 9 students or $30.00 \%$ stated that they encountered difficulties sometimes.

From these results it can be seen that it turns out that most students still experience difficulties in terms of pouring ideas or ideas in the form of poetry. From the questionnaire used to measure the initial knowledge and experience of writing poetry of students, we obtained information that some students never do poetry writing activities outside of school. This can be seen from the answers of 5 students or $16.67 \%$ who stated that they never write poetry outside of school, both at home and. Whereas those who had written poetry outside of school were only $50.00 \%$ or around 15 students, $33.33 \%$ or 10 students stated that sometimes they did poetry writing activities outside of school.

On the results of a questionnaire stating that students were happy to get the task of writing poetry in school there were 18 students or $60.00 \%$. Students who sometimes feel happy to get the task of writing poetry in school amounted to 5 students with a percentage of $16.67 \%$. There were 7 students who felt displeased about the task of writing poetry at school or $23.33 \%$.

As many as 20 students with the percentage expressed difficulty in composing words when writing poetry, 3 students or $10.00 \%$ felt no difficulty when composing words in writing poetry as well as 7 students sometimes having difficulty writing poetry. This shows that students still do not have sufficient vocabulary to write poetry. Whereas in using ideas and imagination there are $18(60.00 \%)$ students find it difficult, $10(33.33 \%)$ students sometimes, and $2(6.67 \%)$ students do not feel difficulties.

\section{CONCLUSION}

Based on the study of literature and the results of the questionnaire it can be concluded (1) learning Indonesian, especially writing poetry is still less liked by most elementary school students, (2) students do not like writing activities and feel less happy if given the task to write poetry, (3 ) students lack interest in learning to write poetry, (4) students lack attention and concentration in learning to write poetry. Using a constructivism and whole language approach can improve poetry writing skills for elementary school students. However, research needs to be done experimentally so that some of the writer's beliefs can be proven empirically. 


\section{BIBLIOGRAPHY}

Arfiani Sinta. 2016. Improving Skill Writing Skills on the Beauty of Nature Theme Using the Audiovisual Assisted Whole Language Approach in Class V Students of SDN 1 Tumpangkrasak Kudus. Essay. Kudus

Hariyanto. 2009. Whole Language Approach as an Effort to Increase the Ability to Write Experiences in Learning Indonesian. Unpublished thesis. Surakarta: Sebelas Maret University Postgraduate Program.

Ministry of National Education. 2006. Content Standards for Elementary and Secondary Education units. Jakarta. Minister of Education Regulation Number 22 of 2006.

Murtono. 2017. Plan and Manage Innovative Learning Models (Student Center Learning). Ponorogo: Wade Group.

Santoso Puji, et al. 2008. Elementary Schools Indonesian Language Learning Materials. Jakarta: Open University.

Slamet, St.Y. 2014. Learning Indonesian Language and Literature in Low Class and High Class Elementary Schools. Surakarta: UNS Press.

Sudrajat Akhmad. 2008. Understanding of Approaches, Strategies, Methods, Techniques, Tactics and Learning Models.(online),(https:// akhmadsudrajat.wordpress.com) accessed on 6 February 2019 